\title{
RELIGIOUS VOCABULARY IN AROMANIAN COMPARED TO ROMANIAN
}

\author{
TOMASZ KLIMKOWSKI
}

\begin{abstract}
Anstract: The first layer of Aromanian Christian terminology is common for all the Balkan Romance languages. It contains a number of inherited Latin terms and some early assimilated Greek loanwords, due to the Oriental origin of Christianity. As for the later layer, the compound of terms related to ecclesiastical organisation and liturgy or to more sophisticated doctrinal concepts, the Balkan Romance languages substantially differ. In Romanian, it was formed on the basis of Slavonic (or Greek via Slavonic), which was used in the Romanian Orthodox Church by the $17^{\text {th }}$ century. The liturgical language of the Aromanians was Greek (maybe except for Moscopole) and therefore, Aromanian mainly based its religious terminology on Greek, but also on Turkish and Albanian, which can be seen in the Aromanian Missal from the second half of the $18^{\text {th }}$ century. In the next centuries, Aromanian religious vocabulary was strongly influenced by Romanian. The contemporary versions of religious texts, including the Bible (e.g. Caciuperi’s translations), introduce a series of Romanian terms instead of the old ones.
\end{abstract}

Tomasz Klimkowski, Adam Mickiewicz University, Faculty of Modern Languages and Literatures, Al. Niepodległości 4, 61-874 Poznań, Poland, e-mail: tomaszklimkowski@gmail.com

Key words: Aromanian, Romanian, religious vocabulary, Christian, Greek, Church Slavonic, Turkish.

DOI: http://dx.doi.org/10.14746/bp.2015.22.12

The first layer of Aromanian Christian terminology is common for all the Balkan Romance languages (Romanian, Aromanian, Istrian and Meglenite, or at least for Romanian and Aromanian). It was inherited from Latin, but contains a number of Greek terms, due to the Oriental origin of Christianity. These terms can be considered to be "total" or "proper" borrowings (i.e. both the signifier and the signified were borrowed), because they represented notions specific to a new religion that developed in the Greek-speaking world. They were borrowed by Latin before its division into Romance dialects (which became separate languages), since they are attested in the majority of Romance languages. Therefore, all of them must be considered to be Latin terms (as for example, some Celtic words were preserved even in the Balkan area).

\begin{tabular}{|c|c|c|c|}
\hline Greek & Latin & Aromanian & Romanian \\
\hline $\begin{array}{l}\beta \alpha \sigma l \lambda l \kappa \eta \dot{~(\sigma \tau o \alpha ́) ~} \\
\text { 'royal portico' }\end{array}$ & $\begin{array}{l}\text { basilica } \\
\text { 'public building; } \\
\text { church' }\end{array}$ & $\begin{array}{l}\text { bãsear }(i) c \tilde{a} \sim \\
\text { bisearicán } \\
\text { 'church' }\end{array}$ & $\begin{array}{l}+ \text { băse (a)recă, } \\
\text { biserică }\end{array}$ \\
\hline $\begin{array}{l}\beta \alpha \pi \tau i \zeta \omega \\
\text { 'to wash; to baptise' }\end{array}$ & $\begin{array}{l}\text { baptizare } \\
\text { 'to baptise' }\end{array}$ & pãtedz, cf. Alb. pagëzoj & boteza \\
\hline
\end{tabular}

${ }^{1}$ The second form is attested in the north. See Tache Papahagi, Dicționarul dialectului aromân [The Dictionary of the Aromanian Dialect] (Bucureşti: Editura Academiei Române, 2013), 265 


\begin{tabular}{|c|c|c|c|}
\hline Greek & Latin & Aromanian & Romanian \\
\hline $\begin{array}{l}\chi \rho \iota \sigma \tau \iota \alpha v o ́ \varsigma \\
\text { 'Christian' }\end{array}$ & christianus & crishtin & creştin \\
\hline 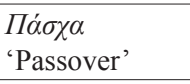 & Paschae & Pashte & Paşti, Paşte \\
\hline $\begin{array}{l}\pi \rho \varepsilon \sigma \beta \hat{\tau} \tau \varepsilon \rho \circ \varsigma \\
\text { 'elder' }\end{array}$ & $\begin{array}{l}\text { pre(s)byter } \\
\text { 'elder; priest' }\end{array}$ & $\begin{array}{l}\text { preftu } \\
\text { 'priest' }\end{array}$ & + preut, preot \\
\hline
\end{tabular}

The other terms that form this first terminological layer were common Latin words from other lexical fields, which began to be associated mostly with Christianity, like crux.

\begin{tabular}{|c|c|c|}
\hline Latin & Aromanian & Romanian \\
\hline $\begin{array}{l}\text { *adjejunare } \\
\text { "to fast' }\end{array}$ & agiun & ajuna \\
\hline $\begin{array}{l}\text { creatio, creationem }{ }^{2} \\
\text { 'creation' }\end{array}$ & $\begin{array}{l}\text { Crãciun Cãrciun } \\
\text { 'Christmas' }\end{array}$ & Crăciun \\
\hline $\begin{array}{l}\text { crux, crucem } \\
\text { 'cross' }\end{array}$ & crutse & cruce \\
\hline $\begin{array}{l}\text { communicare, }{ }^{*} \text { comminicare } \\
\text { 'to communicate' }\end{array}$ & $\begin{array}{l}\text { mi cumãnic } \sim \text { mi cuminic } \\
\text { 'to take communion' }\end{array}$ & cumineca \\
\hline $\begin{array}{l}\text { draco } \\
\text { 'dragon' }\end{array}$ & $\begin{array}{l}d(a) r a c \\
\text { 'devil' }\end{array}$ & drac \\
\hline $\begin{array}{l}\text { paganus } \\
\text { 'villager; civilian; pagan' }\end{array}$ & $\begin{array}{l}\text { pãngãn } \sim \text { pãngãr } \\
\text { 'pagan' }\end{array}$ & păgân \\
\hline $\begin{array}{l}\text { sanctus } \\
\text { 'saint' }\end{array}$ & $\begin{array}{l}\text { sãntu } \sim \text { sintu } \sim \\
\text { sãmtu } \sim \text { simtu, } \\
\text { sãn- } \sim \text { sum- } \sim \text { stã- }\end{array}$ & sânt, sân(t)- \\
\hline $\begin{array}{l}\text { Domine Deus } \\
\text { 'Lord God' }\end{array}$ & Dumnidzãu & Dumnezeu \\
\hline
\end{tabular}

The Latin terms preserved both in Aromanian and Romanian does not exceed 20 units, but they express the most important notions of the Christian religion. Sometimes, the Aromanian variant is more archaic. For example, Arom. bãsear $(i) c \tilde{a}$ and preftu are more similar to the Old Rom. băse(a)recă and preut than to the contemporary Romanian form biserică and preot, with incidental phonetic transforma-

2 The etymology of the term is highly uncertain and controversial. See Alexandru Rosetti, "Românescul Crăciun [Romanian Crăciun]," in Istoria limbii române [The History of the Romanian Language] (Bucureşti: Editura Ştiințifică şi Enciclopedică, 1978), 618-24, Н. Раевский and М. Габинский, ed., Скурт дикиионар етимоложик ал лимбий молдовенешть [Short Etymological Dictionary of the Moldavian Language] (Кишинэу: Едитура Причипалэ а Енчиклопедией С. М., 1978), 214, Alexandru Ciorănescu, Dicționarul etimologic al limbii române [The Etymological Dictionary of the Romanian Language] (Bucureşti: Editura Saeculum I.O., 2002), 250-51, Tomasz Klimkowski, „Chrystianizacja ludności romańskiej na Bałkanach w świetle faktów historycznych i językowych [The Christianization of the Romance Population in the Balkans in the Light of Historical and Linguistic Facts]," Balcanica Posnaniensia. Acta et studia XVIII, II (2011): 45. 
tions $([ə]>[\mathrm{i}],[\mathrm{u}]>[\mathrm{o}])$. Also, it should be noticed that the form that evolved from Latin sanctus occurs in both languages only before the names of some saints, mainly in compounds such as Arom. Sãnchetru, Rom. Sâmpietru < Lat. Sanctus Petrus 'Saint Peter', Arom. Stãmãrie, Rom. Sântămărie < Lat. Sancta Maria 'Saint Mary'3, which are actually used as the names of feasts. In other situations, Aromanian uses ayi (< Greek ó $\gamma l o \varsigma$ ) and Romanian - sfânt (<Church Slavonic svętr), for example, Arom. Ayea Yramã, Rom. Sfânta Scriptură 'the Holy Scriptures', although attemps to resuscitate the reflexes of sanctus were made in both of them ${ }^{4}$. Also, in comparison with Romanian, Aromanian has lost (completely or partially) some important Latin terms, which were replaced by other words of different origins:

\begin{tabular}{|c|c|c|}
\hline Latin & Aromanian & Romanian \\
\hline $\begin{array}{l}\text { angelus 'angel' } \\
<\dot{\alpha} \gamma \gamma \varepsilon \lambda o \varsigma \\
\text { 'messenger; angel' }\end{array}$ & $\begin{array}{l}\text { anghil } \\
\text { 'angel' } \\
\text { < Gr. '́x } \gamma \gamma \varepsilon \lambda \partial \varsigma\end{array}$ & $\begin{array}{l}\text { inger } \\
\text { (but: arhanghel 'archangel' } \\
<\text { Gr. } \alpha \rho \chi \alpha ́ \gamma \gamma \varepsilon \lambda o \varsigma \text { ) }\end{array}$ \\
\hline $\begin{array}{l}\text { altare } \\
\text { 'altar' }\end{array}$ & $\begin{array}{l}+\operatorname{altar}(e), \\
\text { ayiudhimã } \\
<\text { Gr. } \dot{\alpha} \gamma l o v \delta \dot{\eta} \mu \alpha \\
\text { 'holy sanctuary', } \\
\text { vimã } \\
<\text { Gr. } \beta \dot{\eta} \mu \alpha \text { 'sanctuary' }\end{array}$ & $\begin{array}{l}\text { altar } \\
\text { (but also: Old Rom. oltar } \\
<\text { Ch.Sl. oltarb) }\end{array}$ \\
\hline $\begin{array}{l}\text { credere } \\
\text { 'to believe' }\end{array}$ & $\begin{array}{l}\text { +cred, } \\
\text { pistipsescu } \\
<\text { Gr. } \pi ı \sigma \tau \varepsilon \dot{\omega} \omega \\
\text { 'to believe' }\end{array}$ & crede \\
\hline $\begin{array}{l}\text { *mirio, mirionem } \\
\text { 'miracle' }\end{array}$ & $\begin{array}{l}\text { ciudã } \sim \text { ciudie } \\
<\text { Sl. čudo, } \\
\text { tha(v)mã } \\
<\text { Gr. } \theta \alpha \dot{v} \mu \alpha\end{array}$ & $\begin{array}{l}\text { minune } \\
\text { (but also: Old Rom. ciudă } \\
<\text { Ch.Sl. čudo) }\end{array}$ \\
\hline $\begin{array}{l}\text { peccatum } \\
\text { 'sin' }\end{array}$ & $\begin{array}{l}\text { +picat, } \\
\text { (a)mãrtie } \\
\text { < gr. } \alpha \mu \alpha \rho \tau i \alpha\end{array}$ & $\begin{array}{l}\text { păcat, } \\
\text { (bu also: greşeală < greşi } \\
<\text { Ch. Sl. grěšiti } \\
\text { 'to sin') }\end{array}$ \\
\hline
\end{tabular}

Interestingly, the majority of Latin terms that exist in Aromanian, but have been lost in Romanian are related to feasts, although there is also one important archaism

\footnotetext{
${ }^{3}$ For more examples see Tiberius Cunia, Dictsiunar a limbãljei armãneascã [Dictionary of the Aromanian Language] (Constanța: Editura Cartea Aromână, 2010), 894-95, Ciorănescu, Dicționarul, 718.

${ }^{4}$ For Aromanian see Apostol Caciuperi, Noulu Testamentu. Cărtică di rugăciuñi şi psalñi [The New Testament. Book of Prayers and Psalms] (Bucureşti: Universalia, 2011) and Dina Cuvata, trans., Bibliea (Sâmta Scripturâ) [Bible (The Holy Scriptures)] (Scopia: Biblioteca Natsionalâ Armânească "Constantin Belemace", 2004). At the same time, ayi and ayiusit are the only forms used by one of the oldest Aromanian texts, a Missal from the $18^{\text {th }}$ century - see Matilda Caragiu-Marioțeanu, ed., Liturghier arominesc. Un manuscris anonim inedit [Aromanian Missal. An Anonymous Unpublished Manuscript] (Bucureşti: Editura Academiei, 1962).
} 
linking Aromanian with the late Church Latin - the meaning 'to pray' attested for the verb (a)or (a)uredz< Lat. orare, like in an inscription from 1731: Viryirã , Muma-l Dumnidzã , orã trã noi pecãtoshlji 'Virgin, Mother of God, pray for us sinners' ${ }^{5}$ :

\begin{tabular}{|l|l|l|}
\hline \multicolumn{1}{|c|}{ Latin } & \multicolumn{1}{|c|}{ Aromanian } & \multicolumn{1}{c|}{ Romanian } \\
\hline $\begin{array}{l}\text { orare } \\
\text { 'to speak; to ask for; } \\
\text { to pray' }\end{array}$ & $\begin{array}{l}\text { (a)or }(\text { a)uredz } \\
\text { 'to wish; to pray' }\end{array}$ & $\begin{array}{l}\text { ura } \\
\text { 'to wish' }\end{array}$ \\
\hline $\begin{array}{l}\text { quadragesima } \\
\text { 'the fortieth' }\end{array}$ & $\begin{array}{l}p(\tilde{a}) \text { reasinj 'fast' } \\
p(\tilde{a}) \text { reasinjle mãri 'Lent' }\end{array}$ & +păresimi 'Lent' \\
\hline $\begin{array}{l}\text { polenta } \\
\text { 'barley porridge' }\end{array}$ & $\begin{array}{l}\text { purindã } \\
\text { 'food eaten during feasts' }\end{array}$ & not attested \\
\hline $\begin{array}{l}\text { opulentus } \\
\text { 'opulent' }\end{array}$ & $\begin{array}{l}\text { purindu } \\
\text { 'a person who does not feast; } \\
\text { pagan' }\end{array}$ & not attested \\
\hline
\end{tabular}

The number of Latin terms would be substantially larger if we took into consideration the other words from the same lexical family as the terms mentioned above. Nevertheless, they are not derived directly from Latin, but were created later, in Balkan Romance (or separately in Aromanian and Romanian), on the basis of an inherited term, according to the rules of the new derivative system. Some of the terms could be very productive. In Aromanian, it refers especially to the terms: crishtin 'Christian'> crishtinescu 'Christian (adj.)', crishtinedz, crishtinipsescu 'to christen', crishtinãtate 'Christianity'; drac 'devil'> drãcurescu, drãtsescu 'devil's', drãcuri(lj) $e$ 'devil thing', drãcoanje, dracsã 'she-devil', drãcos, drãcuros 'diabolical', drãcush 'little devil'; preftu 'priest' > prifteasã 'priest's wife', priftescu 'priest's, priftsãlje 'priesthood', priftame 'clergy'. The majority of these derivatives have exact equivalents in Romanian, so the Aromanian and Romanian words probably continue the same Proto-Balkan Romance form. The others are specific to one of these languages and were formed later or evolved from the Balkan-Romance word in a different way. Surprisingly, Aromanian sources do not record a derivative of bãsearicã. For example, the Romanian word bisericesc is usually expressed by $v \tilde{a} c(u) f e s c u$ (a derivative of vãcufe 'religious institution', which is derived from Turkish vaklf 'religious foundation') or as a periphrastic construction di bãsearicã. However, Aromanian still uses pãtigiune, the Romanian equivalent of which, botejune, is attested only in old texts and is already given as obsolete in Scriban's dictionary. Both of them seem to be reflexes of Balkan-Romance *bătedzăciune. Additionally, Romanian has the advantage of Aromanian there due to a bigger number of inherited Latin terms. For example, Aromanian did not develop a series of derivatives based on the Latin word peccatum 'sin' (Rom. păcat > păcătui 'to sin', păcătos 'sinner'), because picat became obsolete and was replaced by the Greek loanwords amãrtie.

\footnotetext{
5 Matilda Caragiu-Marioțeanu, "Literatura aromînească veche [Old Aromanian Literature]," in Caragiu-Marioțeanu, Liturghier, 112. We have reproduced this text in modern Aromanian orthography.
} 
Balkan Romance Christian terminology of Latin origin may be helpful in elucidating the problem of ethnogenesis. For example, at least one of these terms represents an important argument against the North Danube (Dacian) origin of the Romanians. The word basilica 'church' had initially a different meaning and acquired its religious connotations in the $4^{\text {th }}$ century, when Christianity began to be not only tolerated, but also favoured by the authorities. Christians did not have the right to gather publicly until the Edict of Milan (313) and only then the notion of church could appear. Since old temples had a limited space and Christians associated them with abominable practices such as animal sacrifices, they preferred to use public buildings called basilicas, which changed its meaning to that of 'church'. These new meanings could not have developed in Dacia, in a province abandoned by the Romans in 271 (nearly one century earlier), where basilicas, regardless of their public role, were not built anymore. Moreover, in the year of Roman evacuation, Christianity itself was just one of many religions of the Roman Empire. Even if there is archaeological evidence of it in the Roman Dacia, it could not have spread and consolidated there without the support of the Roman state. The huge success of Christianity is due to political factors. In all the cases, the new religion was embraced by the ruler of a country and imposed by force on his subjects. In post-Roman Dacia, there was not a political centre that would have promoted Christianity in the Roman rite and in the Latin language. For this reason, the new meaning of basilica could have appeared only in the South Danube territory, which was still within the Roman Empire and shared some linguistic evolutions with the other Latin areas. Between the $5^{\text {th }}$ and the $7^{\text {th }}$ century, when the Slavs settled in the Balkan Peninsula, Balkan Romance was definitively separated from the rest of the Romance territory. Therefore, it never replaced the term basilica with ecclesia (the initial meaning of which was 'congregation'), like Western Romance (Fr. église, Sp. iglesia, Port. igreja), Italian (chiesa) and Albanian (kishë). The term ecclesia is thought to have acquired the meaning of 'church' in the $6^{\text {th }}$ century ${ }^{6}$; the reflexes of the term basilica in the Western Romance languages refer to a Romanesque church and are borrowings from Medieval Latin. The same situation as in Balkan Romance can be found in Rhaeto-Romance, in which basilica survives as baselgia, because of its isolation from the other varieties of Romance after the invasion of Germanic tribes.

Nevertheless, Balkan Romance generally coincides with the other Romance languages in the Christian terminology inherited from Latin. The most important difference consists in the loss of a number of terms that survived in the West or even in Albanian. ${ }^{7}$ For this reason, the Christian terminology of Latin origin in Aromanian and Romanian does not form a coherent whole and contains serious gaps, which had to be filled by later borrowings. Therefore, the later terminological layers of Christian terminology mainly concern liturgy and Church organisation, but also more abstract and precise concepts of Christian doctrine. The origin of these layers in Aromanian

\footnotetext{
${ }^{6}$ Albert Dauzat, Jean Dubois, and Henri Mitterand, Nouveau dictionnaire étymologique et historique (Paris: Larousse, 1964), 256.

${ }^{7}$ See Klimkowski, "Chrystianizacja”, 48.
} 
compared to Romanian reflects the progressive increase of differences in the ethnic, political and cultural conditions of life between Aromanians and Romanians, which marked the development of their languages. The Romanians succeeded to creating in the course of the Middle Ages two autonomous states and even if the Slavs dominated Wallachian and Moldavian public life for centuries, the Romanian cultural emancipation already began in the $16^{\text {th }}$ century. The Romanian Church, which had been organised in the Byzantine-Slavonic rite and had initially used the Slavonic Church language, introduced Romanian liturgy in the $17^{\text {th }}$ century. The Aromanians as a community, except for the first phase of the Second Bulgarian Empire, never played an important role in the political life of the region and were culturally dominated by the Greeks. There was not a separate Vlach church organisation and the Aromanians were part of the Greek Orthodox Church, which only used Greek in liturgy. Even in Moscopole, where the population was mostly Aromanian and where Aromanian books were printed, the language of education and liturgy was Greek. Nevertheless, there is direct evidence to confirm that Aromanian was used there as a liturgical language $^{8}$ and also, a manuscript with the text of Aromanian liturgy, which probably dates from the second half of the $18^{\text {th }}$ century and is thought to have been written in Moscopole. ${ }^{9}$ Nevertheless, the glory days of Moscopole represent a very short episode (no more than a few decades) and after the fall of the city (1769-1788), similar conditions never existed again. The Church language of the Aromanians remained Greek, with some exceptions. From 1860-1948, the Romanian state maintained in the Balkans numerous schools and churches that used and promoted the Romanian language and identity among the Aromanians. However, it is not clear if priests served the liturgy in Romanian or Aromanian. Even if it was Aromanian, it probably was strongly influenced by Romanian. At any rate, Romanian became the liturgical language of the Aromanians who left their native countries and settled in Romania in the 1920's and 1930's. In Macedonia, there are no Aromanian churches and believers have to attend religious services in Macedonian, but there exists one Aromanian church in Korçë (Albania) where Aromanian is a liturgical language.

Because of all these historical factors, Aromanian lacks words of Church Slavonic origin which form the core of Romanian religious terminology. Instead of them, Aromanian has borrowed terms of Greek origin. Some of them occur in Romanian, but the majority were adopted via Slavonic. The lack of Slavonic terminology and the direct character of Greek loanwords are two major characteristics of Aromanian religious terminology in comparison to Romanian. The only Slavic words seem to be rather Old Slavic or Bulgarian (Macedonian) than Church Slavonic. Generally, they coincide with Slavic (mainly Church Slavonic) borrowings in Romanian:

\footnotetext{
${ }^{8}$ Caragiu-Marioțeanu, "Literatura", 118.

9 "Locul liturghierului în literatura aromînească [The Place of the Missal in Old Aromanian Literature]," in Caragiu-Marioțeanu, Liturghier, 118-22.
} 


\begin{tabular}{|l|l|l|}
\hline \multicolumn{1}{|c|}{ Slavic } & \multicolumn{1}{|c|}{ Aromanian } & \multicolumn{1}{c|}{ Romanian } \\
\hline $\begin{array}{l}\text { duxъ } \\
\text { 'ghost, spirit' }\end{array}$ & duh & duh \\
\hline $\begin{array}{l}\text { milo 'mercy', } \\
\text { milovati 'to have mercy' }\end{array}$ & $\begin{array}{l}\text { njilãa, } \\
\text { nijluescu }\end{array}$ & $\begin{array}{l}\text { milă, } \\
\text { a milui }\end{array}$ \\
\hline $\begin{array}{l}\text { raj } \\
\text { 'paradise' }\end{array}$ & rai & rai \\
\hline $\begin{array}{l}\text { pops } \\
\text { 'priest' }\end{array}$ & popa & popă \\
\hline
\end{tabular}

As for Greek terms, the direct character of borrowing (in Aromanian) in contrast to the indirect one, via Slavonic (in Romanian), is demonstrated by the phonetic or morphological form of loanwords:

\begin{tabular}{|c|c|c|}
\hline Greek & Aromanian & Romanian \\
\hline 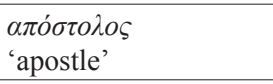 & apostol & $\begin{array}{l}\text { apostol } \\
<\text { Ch.S1. apostolb }\end{array}$ \\
\hline 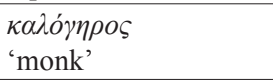 & cãlugru $>$ cãlugãr $\sim$ caloir & $\begin{array}{l}\text { călugăr } \\
<\text { Ch.Sl. kalugerъ }\end{array}$ \\
\hline $\begin{array}{l}\varepsilon v \lambda \dot{\alpha} \beta \varepsilon l \alpha \\
\text { 'piousness' }\end{array}$ & evlavie $\sim$ ivlavie & $\begin{array}{l}\text { evlavie } \\
<\text { Ch.Sl. evlavija }\end{array}$ \\
\hline $\begin{array}{l}\text { Evopía } \\
\text { 'parish' }\end{array}$ & enurie $\sim$ inurie & $\begin{array}{l}\text { enorie } \\
<\text { Ch.Sl. jenorija }\end{array}$ \\
\hline $\begin{array}{l}\text { влібколоৎ } \\
\text { 'bishop' }\end{array}$ & episcop $\sim$ ipiscup & $\begin{array}{l}\text { episcop } \\
<\text { Ch.Sl. jepiskops }\end{array}$ \\
\hline 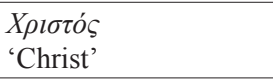 & Hristo & $\begin{array}{l}\text { Hristos } \\
<\text { Ch.Sl. Xristosb }\end{array}$ \\
\hline 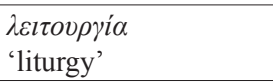 & lituryie $\sim$ lutruyie & $\begin{array}{l}\text { liturghie } \\
<\text { Ch.Sl. liturgija }\end{array}$ \\
\hline 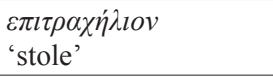 & pitrãhilje $\sim$ pãtrãhilje & $\begin{array}{l}\text { patrafir } \\
<\text { Ch.Sl. petrohilb }\end{array}$ \\
\hline 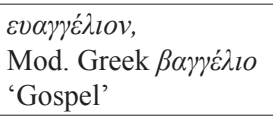 & vãnghelj $\sim$ vinghelj & $\begin{array}{l}\text { evanghelie } \\
<\text { Ch.Sl. jevangelije }\end{array}$ \\
\hline
\end{tabular}

For example, Arom. lituryie lutruyie presents the palatalisation of [g] to [j] before [i], according to Modern Greek pronunciation, while Rom. liturghie follows the Slavonic form liturgija, adopted with [ $\mathrm{I}]$. Arom. vãnghelj $\sim$ vinghelj is a reflexive of $\beta \alpha \gamma \gamma \dot{\lambda} \lambda \imath$, the modern Greek variant of $\varepsilon v \alpha \gamma \gamma \dot{c} \lambda \imath o v$ (the loss of the initial [e], transformation of [i] in [j], which forms with [1] the palatal consonant [K]), and Rom. evanghelie reproduces Ch.Sl. jevangelije (where [e] and [i] are preserved). Also, the Church Slavonic borrowing is confirmed by the neuter form of Rom. evanghelie, because Slavic neuters usually become feminine in Romanian and Aromanian, cf. Rom. milă , Arom. njilã < S1. milo. In turn, Arom. vãnghelj vinghelj must have been derived directly from Greek. Besides, when unstressed, the Greek masculine ending -os is usually dropped in Aromanian and when stressed, it is rendered as - $o$. According 


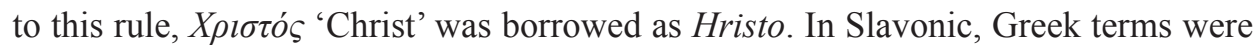
usually adopted without this ending (it was replaced with - $b$ ). One of the exceptions is Xristosb, in which -os was preserved, so the Romanian form Hristos has to be explained through the Slavonic version of this name. However, the Slavonic influence upon the form of Greek terms in Aromanian is not impossible. For example, cãlugru > cãlugã $r$ would be a reflexive of the Slavonic form kalugerb (like Romanian

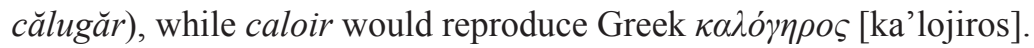

Greek loanwords in the religious terminology of Aromanian are just as important as Church Slavonic loanwords in that of Romanian. Most often, if an Aromanian term of Greek origin does not have an exact equivalent in Romanian, it is expressed there by a Church Slavonic word:

\begin{tabular}{|c|c|c|}
\hline Greek & Aromanian & Romanian \\
\hline 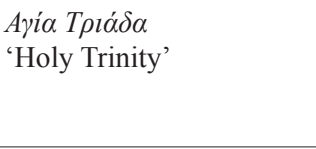 & Ayia-Triadha & $\begin{array}{l}\text { Old Rom. Sfânta Troiță } \\
<\text { Ch.Sl. Svętaja Trojica, } \\
\text { Sfânta Treime } \\
\text { (< Rom. trei 'three') }\end{array}$ \\
\hline $\begin{array}{l}\varepsilon v \chi \varepsilon ́ \lambda \alpha l o v \\
\text { 'chrism' }\end{array}$ & efhele & $\begin{array}{l}\text { maslu } \\
<\text { Ch.S1. maslo }\end{array}$ \\
\hline $\begin{array}{l}\varepsilon \xi o \mu o \lambda o ́ \gamma \eta \sigma l \varsigma \\
\text { 'confession' }\end{array}$ & exumuluyie & $\begin{array}{l}\text { spovedanie } \\
<\text { Ch.Sl. spovědanije }\end{array}$ \\
\hline 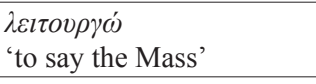 & lituryisescu & $\begin{array}{l}\text { sluji } \\
<\text { Ch.Sl. služiti }\end{array}$ \\
\hline $\begin{array}{l}\pi v \varepsilon v \mu \alpha \tau \imath \kappa o ́ \varsigma \sim \pi \lambda \imath \mu \alpha \tau \imath \kappa o ́ \varsigma \\
\text { 'confessor' }\end{array}$ & $\begin{array}{l}\text { pramatico } \sim \text { prãmatico } \sim \text { plima- } \\
\text { tico }\end{array}$ & $\begin{array}{l}\text { duhovnic } \\
<\text { Ch.S1. duchovnikb }\end{array}$ \\
\hline $\begin{array}{l}\psi v \chi o \chi \alpha ́ \rho \tau \imath \\
\text { 'pomelnic' }\end{array}$ & psihuharte & $\begin{array}{l}\text { pomelnic } \\
<\text { Ch.S1. poměnbnikb }\end{array}$ \\
\hline
\end{tabular}

Although Turkish terms were initially related to Islam, some of them were assimilated by Aromanian Christian terminology and became quite common. It has to be noticed that Romanian does not use any of them.

\begin{tabular}{|c|c|c|}
\hline Turkish & Aromanian & Romanian \\
\hline $\begin{array}{l}\text { bereket versin } \\
\text { 'may you have prosperity' }\end{array}$ & biricheat-virsãn & $\begin{array}{l}\text { bogdaproste } \\
<\text { Ch.Sl. Bogz da oprostits } \\
\text { 'may God forgive you' }\end{array}$ \\
\hline $\begin{array}{l}\text { rica etmek } \\
\text { 'to pray' }\end{array}$ & fac arigeae & a se ruga \\
\hline $\begin{array}{l}\text { kurban } \\
\text { 'lamb for sacrifice' }\end{array}$ & $\begin{array}{l}\text { curban } \\
\text { 'offering', }\end{array}$ & $\begin{array}{l}\text { jertfă } \\
<\text { Ch.S1. žrztva }\end{array}$ \\
\hline $\begin{array}{l}\text { ispat } \\
\text { 'testimony', Alb. 'witness' }\end{array}$ & $\begin{array}{l}\text { ispate } \\
\text { 'martyr' }\end{array}$ & $\begin{array}{l}\text { mucenic } \\
<\text { Ch.Sl. mučeniks }\end{array}$ \\
\hline $\begin{array}{l}\text { insaf } \\
\text { 'mercy' }\end{array}$ & $i(n) s a f e$ & $\begin{array}{l}\text { milă } \\
<\text { Ch.S1. milo }\end{array}$ \\
\hline $\begin{array}{l}\text { vakıf } \\
\text { 'religious foundation' }\end{array}$ & $\begin{array}{l}\text { vãc(u)fescu } \\
<v \tilde{a} c u f e \\
\text { 'religious institution' }\end{array}$ & $\begin{array}{l}\text { bisericesc } \\
<\text { biserică } \\
\text { 'church' }\end{array}$ \\
\hline
\end{tabular}


While Turkish terms are well attested in Aromanian Missal, further religious texts are strongly influenced by Romanian. This phenomenon goes back to the second half of the $19^{\text {th }}$ century, when the first Romanian school and churches were founded for the Aromanians, and continued in the $20^{\text {th }}$ century, when many Aromanians emigrated to Romania. Such a case is represented by Apostol Caciuperi, who translated into Aromanian The New Testament, psalms and the most important prayers. ${ }^{10}$

\begin{tabular}{|c|c|c|}
\hline Aromanian & Caciuperi's version & Romanian \\
\hline 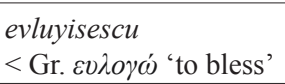 & ghinecuvintedz & binecuvânta \\
\hline $\begin{array}{l}\text { stãvrusire 'crucifixion' } \\
<\text { stãvrusescu } \\
<\text { Gr. } \sigma \tau \alpha v \rho \omega ́ v \omega \\
\text { 'to crucify' }\end{array}$ & arãstignire & $\begin{array}{l}\text { răstignire 'crucifixion' } \\
<\text { răstigni }<\text { Ch.Sl. rastęnati } \\
\text { 'to crucify' }\end{array}$ \\
\hline 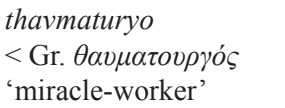 & fãcãtor di thavmate & făcător de minuni \\
\hline
\end{tabular}

The religious terms that occur there are very often Aromanised forms of Romanian words, for example ghinecuvintedz < binecuvânta 'to bless', many of them of Church Slavonic origin, like arãstignire < răstignire 'crucifixion', although Aromanian has their equivalents, mostly of Greek origin. The terminology used by Caciuperi includes also calques such as fãcãtor di thavmate 'miracle-worker', which consists in adopting the Romanian syntagm făcător de minuni, where the Romanian element minuni 'miracles' was replaced by Aromanian thavmate. In terms of vocabulary, the other translation of the Bible by Dina Cuvata ${ }^{11}$, an Aromanian from Macedonia, sounds more natural.

As a result of different foreign influences, both Aromanian and Romanian created pairs or even a bigger series of synonyms in religious terminology. Since the phenomenon of absolute synonymy is very rare, the terms with the same or a very similar meaning tend to differentiate, stylistically or semantically, especially in Romanian, in which religious terminology is more precise and stable due to the longer tradition of its use and to its ecclesiastical back-up. In Aromanian, such synonyms function differently than in Romanian, because some of them are used only in a territory and are unknown in another one. Moreover, this vocabulary is not currently used nor controlled by a religious institution, except for some isolated cases. Therefore, it is less coherent as a whole, more variable and the interchangeability of terms is still possible, even in the case of basic notions.

\footnotetext{
10 Caciuperi, Noulu Testament.

11 Cuvata, Bibliea (Sãmta Scripturã).
} 


\begin{tabular}{|c|c|}
\hline Aromanian & Romanian \\
\hline \multicolumn{2}{|c|}{ 'faith' } \\
\hline $\begin{array}{l}\text { piste }<\text { Gr. } \pi i \sigma \tau \iota \varsigma \\
\text { dina }(\mathrm{N})<\text { Turk. din } \\
\text { imane }<\text { Turk. iman } \\
\text { fede }<\text { It. fede } \\
\text { bes } \tilde{a}<\text { Alb. besë } \\
\text { vereauã } \sim \text { vearã }<\text { S1. věra }\end{array}$ & credință $<$ crede \\
\hline \multicolumn{2}{|c|}{ 'priest' } \\
\hline $\begin{array}{l}\text { preftu }<\text { Lat. pre }(\text { s)byter } \\
\text { popa }<\text { Sl. pops } \\
\text { pãp } \tilde{a}<\text { Gr. } \pi \alpha \pi \dot{\alpha} \varsigma\end{array}$ & $\begin{array}{l}\text { preot }<\text { Lat. pre }(\text { s)byter } \\
\text { popă }<\text { Sl. pop } ъ\end{array}$ \\
\hline \multicolumn{2}{|c|}{ 'to fast' } \\
\hline $\begin{array}{l}\text { agiun }<\text { Lat. *adjejunare } \\
\text { mãrsinedz }<\text { Sl. ? } \\
\text { tsãn pãreasinj }<\text { Lat. tenere }+ \text { quadragesima }\end{array}$ & $\begin{array}{l}\text { ajuna }<\text { Lat. } * \text { adjejunare } \\
\text { post } i<\text { Sl. postiti }\end{array}$ \\
\hline \multicolumn{2}{|c|}{ 'to pray' } \\
\hline $\begin{array}{l}+ \text { (mi) } \text { rog }<\text { Lat. rogare } \\
\text { (a) or } \sim \text { (a) uredz }<\text { Lat. orare } \\
\text { fac arigeae }<\text { Turk. rica etmek } \\
\text { pãrãcãlsescu }<\text { Gr. } \pi \alpha \rho \alpha \alpha \lambda \omega \dot{~}\end{array}$ & a se ruga $<$ Lat. rogare \\
\hline \multicolumn{2}{|c|}{ 'ghost, spirit' } \\
\hline 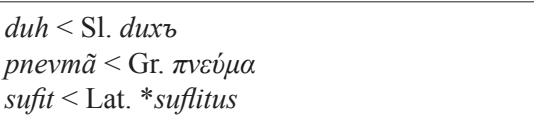 & $d u h<\mathrm{Sl} . d u x b$ \\
\hline
\end{tabular}

\section{BIBLIOGRAPHY}

Apostol Caciuperi, Noulu Testamentu. Cărtică di rugăciuñi şi psalñi [The New Testament. Book of Prayers and Psalms] (Bucureşti: Universalia, 2011).

Dumitru Carabaş, "Elements of Religious Vocabulary in the Language of the Aromanians of Romania," Studii şi cercetări de onomastică şi lexicologie (SCOL) VI, 1-2 (2013),

http://cis01.central.ucv.ro/litere/activ_st/SCOL/revista_scol_2013/CARBAS.pdf.

Matilda Caragiu-Marioțeanu, ed., Liturghier aromînesc. Un manuscris anonim inedit [Aromanian Missal. An Anonymous Unpublished Manuscript] (Bucureşti: Editura Academiei, 1962).

Matilda Caragiu-Marioțeanu, "Literatura aromînească veche [Old Aromanian Literature]," in CaragiuMarioțeanu, Liturghier, 111-118.

Matilda Caragiu-Marioțeanu, "Locul liturghierului în literatura aromînească [The Place of the Missal in Old Aromanian Literature]," in Caragiu-Marioțeanu, Liturghier, 118-22.

Matilda Caragiu Marioțeanu, "Biblia la aromâni [Bible at the Aromanians]," Revista de istorie şi teorie literară XXXVIII (1990): 3-4.

Alexandru Ciorănescu, Dicționarul etimologic al limbii române [The Etymological Dictionary of the Romanian Language] (Bucureşti: Editura Saeculum I.O., 2002), 250-51, 718.

Tiberius Cunia, Dictsiunar a limbãljei armãneascã [Dictionary of the Aromanian Language] (Constanța: Editura Cartea Aromână, 2010), 894-95. 
Dina Cuvata, trans., Bibliea (Sãmta Scripturã) [Bible (The Holy Scriptures)] (Scopia: Biblioteca Natsionalã Armãneascã "Constantin Belemace", 2004).

Albert Dauzat, Jean Dubois, and Henri Mitterand, Nouveau dictionnaire étymologique et historique (Paris: Larousse, 1964), 256.

Tomasz Klimkowski, „Chrystianizacja ludności romańskiej na Bałkanach w świetle faktów historycznych i językowych [The Christianization of the Romance Population in the Balkans in the Light of Historical and Linguistic Facts]," Balcanica Posnaniensia. Acta et studia XVIII, II (2011): 45.

Tache Papahagi, Dicționarul dialectului aromân [The Dictionary of the Aromanian Dialect] (Bucureşti: Editura Academiei Române, 2013), 265.

Alexandru Rosetti, "Românescul Crăciun [Romanian Crăciun]," in Istoria limbii române [The History of the Romanian Language] (Bucureşti: Editura Ştiințifică şi Enciclopedică, 1978), 618-24.

H. Раевский and М. Габинский, ed., Скурт дикиионар етимолоӂик ал лимбий молдовенешть [Short Etymological Dictionary of the Moldavian Language] (Кишинэу: Едитура Причипалэ а Енчиклопедией С. М., 1978), 214. 
